\title{
PENGARUH KEKUASAAN DAN KEPERCAYAAN TERHADAP ORGANIZATIONAL CITIZENSHIP BEHAVIOR (OCB) PADA GURU SEKOLAH DASAR NEGERI (SDN) DI RAWALUMBU BEKASI
}

\begin{abstract}
Jamilah Syairoh ${ }^{1}$
Abstract: The objective of this research is to obtain information about the effect of power and trust on teachers organizational citizenship behavior (OCB). This research used survey method with path analysis. Sample in this research was used simple random sampling. The conclusions of this research are: (1) There is a positive direct effect of power on organizational citizenship behavior (OCB). (2) There is a direct positive effect of trust on teacher organizational citizenship behavior (OCB). (3) There is a positive direct effect of power on trust.
\end{abstract}

Keywords: Power, trust and organizational citizenship behavior (OCB).

\section{PENDAHULUAN}

Salah satu tujuan pendidikan adalah untuk menciptakan manusia yang berkualitas. Kualitas manusia Indonesia tersebut dihasilkan melalui penyelenggaraan pendidikan yang bermutu. Sekolah berada di titik sentral kehidupan masyarakat, maka kepala sekolah berada di titik yang paling sentral dari kehidupan sekolah. Keberhasilan atau kegagalan suatu sekolah dalam menampilkan kinerjanya secara memuaskan banyak tergantung pada kualitas kepemimpinan kepala sekolah. Program kerja sekolah yang telah disusun dalam rangka mencapai target-target tertentu bisa sia-sia apabila tidak disokong oleh kinerja guru yang optimal.

Berkaitan dengan pengembangan satuan pendidikan yang sukses, maka perlu upaya untuk memperbaiki kualitas pendidikan di Indonesia. Diperlukan perbaikan yang menyeluruh terhadap unsur-unsur yang saling terkait di dalamnya. Salah satu unsur yang mempunyai peranan sangat penting dalam meningkatkan kualitas pendidikan tersebut adalah tenaga pendidik, dalam hal ini adalah guru. Guru merupakan salah satu komponen esensial dalam suatu sistem pendidikan.

Kinerja guru sangat menentukan kinerja sekolah, karena pendidikan bermutu hanya bisa diraih jika sekolah memiliki guru-guru yang bermutu. Untuk tercapainya tujuan tersebut dibutuhkan perilaku in-role (organizational citizenship behavior) guru itu sendiri. Peningkatan perilaku in-role tersebut didukung oleh kepemimpinan kepala sekolah dan kepercayaan dari para guru. Kekuasaan yang baik akan mempengaruhi tingkat kepercayaan anggota terhadap pimpinannya sehingga dapat memberikan pengaruh positif untuk peningkatan organizational citizenship behavior (OCB), demikian pula sebaliknya seorang pimpinan yang baik akan memberikan kewenangan dan pendelegasian tugas kepada anggotanya yang didasari atas kepercayaan.

Organizational citizenship behavior (OCB) merupakan istilah yang digunakan untuk mengidentifikasi perilaku guru sehingga dia dapat disebut sebagai "anggota yang baik" dalam organisasi sekolah. Perilaku ini cenderung melihat guru sebagai makhluk sosial (menjadi anggota organisasi), dibandingkan sebagai makhluk individual yang mementingkan diri sendiri. Manusia sebagai makhluk sosial mempunyai kemampuan

${ }^{1}$ Staf Pengajar SDIT Ar Rahman Rawalumbu Bekasi 
untuk memiliki empati kepada orang lain dan lingkungannya, menyelaraskan nilai-nilai yang dianutnya dengan nilai-nilai yang dimiliki lingkungannya untuk menjaga dan meningkatkan interaksi sosial yang lebih baik dan melakukan sesuatu tanpa mengharapkan imbalan. Jika guru dalam organisasi memiliki OCB maka usaha kepala sekolah dalam mengorganisir kegiatan-kegiatan guru akan lebih mudah karena guru dapat mengendalikan perilakunya sendiri atau mampu memilih perilaku terbaik untuk kepentingan organisasinya.

Kekuasaan merupakan kapasitas mempengaruhi perilaku orang lain. Para pemimpin menggunakan kekuasaan sebagai sarana untuk mewujudkan tujuan kelompok. Para pemimpin mencapai tujuan, dan kekuasaan adalah sarana untuk memudahkan usaha mereka tersebut. Kemampuan seorang pemimpin untuk mempengaruhi kelompoknya dalam mencapai tujuan organisasi membutuhkan proses dan pendekatan tertentu yang dapat merubah kepercayaan anggotanya guna pencapaian mutu yang lebih baik. Kekuasaan yang kuat akan mempengaruhi tingkat kepercayaan anggota terhadap pimpinannya sehingga dapat memberikan pengaruh positif untuk peningkatan organizational citizenship behavior, demikian pula sebaliknya seorang pemimpin yang baik akan memberikan kewenangan dan pendelegasian tugas kepada anggotanya yang didasari oleh kepercayaan.

Berdasarkan pemaparan masalah dan pentingnya peranan kekuasaan serta kepercayaan terhadap organizational citizenship behavior (OCB) guru. Dengan demikian hasil penelitian ini dapat berguna untuk meningkatkan organizational citizenship behavior $(O C B)$ guru di Rawalumbu, Bekasi.

\section{Organizational Citizenship Behavior (OCB)}

Tentang organizational citizenship behavior (OCB) Robbins dan Timothy (2011:60) menyatakan, "organizational citizenship behavior (OCB) is discretionary behavior that is not part of an employee's formal job requirements but nevertheless promotes the effective functioning of the organization". Organizational citizenship behavior (OCB) adalah perilaku sukarela yang bukan merupakan bagian dari persyaratan formal seorang karyawan pada pekerjaannya namun ia tetap meningkatkan fungsi efektif dari organisasi.

Sementara Greenberg (2008:434) mengatakan bahwa, "OCB is generally no included as part of any standard performance measures that a company gathers about its employees." OCB umumnya adalah tidak termasuk sebagai bagian dari ukuran standar kinerja bahwa sebuah perusahaan dapat memberikan fungsi karyawannya. Istilah organizational citizenship behavior (OCB) menurut Campbell dan Nelson (2009:196) menyatakan "OCB is enhanced most trough employee involvement programs aimed at engaging employees in the work organization rather than through employee involvement in employment decisions in nonunion operation." OCB adalah peningkatan sebagian besar program yang melibatkan karyawan melalui keterlibatan karyawan dalam kerja organisasi ketimbang melalui keterlibatan karyawan dalam keputusan kerja dalam operasi nonunion.

Dalam sebuah jurnal internasional milik Karfestani et al Institute of Interdisciplinary Business Research dijelaskan bahwa, "organizational citizenship behavior is a completely voluntary behavior that the rewarding system is not able to identify it directly but altogether it increases the effective performance in the organization." Dapat dikatakan bahwa Organizational citizenship behavior (OCB) adalah perilaku sukarela sepenuhnya bahwa sistem penghargaan tidak mampu mengidentifikasi secara langsung tapi semua itu dapat meningkatkan kinerja yang efektif dalam organisasi.

Terkait dengan organizational citizenship behavior (OCB) Newstroom dan Davis (2002:217) menjelaskan, "organizational citizenship is often marked by its spontaneity, its 
voluntary nature, its constructive impact on results, its unexpected helpfullness to others, and the fact that it is optional". Dapat dikatakan bahwa organizational citizenship adalah sering ditandai dengan spontanitas, sifat sukarela, dampak membangun terhadap hasil, sikap menolong yang tak terduga kepada orang lain, dan fakta bahwa itu adalah sebuah pilihan.

Dari beberapa konsep tersebut dapat disintesiskan bahwa organizational citizenship behavior (OCB) adalah perilaku sukarela sepenuhnya individu pada pekerjaan yang bukan merupakan bagian dari persyaratan formal untuk meningkatkan fungsi efektif organisasi dengan indikator: (1) keterlibatan dalam kerja organisasi, (2) spontanitas, (3) sikap menolong, (4) luasnya persepsi terhadap pekerjaan, (5) pengabdian.

\section{Kekuasaan}

Berbicara tentang kekuasaan, Hughes et al (2009:136), memberikan penjelasan mengenai definisi kekuasaan sebagai, "power is the capacity to cause change, influence is the degree of actual change in a target person's attitudes, values, beliefs, or behaviors." Kekuasaan adalah kemampuan yang dapat menyebabkan perubahan, mempengaruhi tingkat perubahan yang sebenarnya terhadap sasaran sikap, nilai, kepercayaan, atau perilaku seseorang.

Dalam hal ini, McShane (2010:300) mengemukakan bahwa, "power is the capacity of a person, team, or organization to influence others." Dapat diartikan bahwa kekuasaan adalah kemampuan seseorang, tim, atau organisasi untuk mempengaruhi orang lain. Schermerhorn et al (2011: 278), memberikan definisi kekuasaan sebagai, "power is the ability to get someone to do something you want done or the ability to make things happen in the way you want to them to." Dengan kata lain kekuasaan adalah kemampuan untuk mendapatkan seseorang agar melakukan sesuatu yang diinginkan atau kemampuan untuk mewujudkan sesuatu terjadi sesuai dengan yang diinginkan.

McClelland dalam Gibson (2006:294) menjelaskan, "power as the desire to have an effect on others. This effect may be shown basically in three ways: (1) by strong action, by giving help or advice, by controlling someone; (2) by action that produces emotion in others; and (3) by concern for reputation." Kekuasaan didefinisikan sebagai keinginan untuk mempengaruhi orang lain. Efek ini dapat ditampilkan berdasarkan pada tiga cara: (1) dengan tindakan yang kuat, yaitu dengan memberikan bantuan atau saran, ataupun dengan mengendalikan seseorang, (2) dengan tindakan yang menghasilkan emosi pada orang lain, dan (3) dengan kepedulian akan reputasi. Hall (2002:107) mendefinisikan kekuasaan sebagai, "power as a has power over B to the extent that he can get $B$ to do something $B$ would not otherwise do." Kekuasaan sebagai kekuatan yang dimiliki B untuk sejauh mana dia bisa mendapatkan B untuk melakukan sesuatu yang kemungkinan B tidak dapat melakukannya.

Dalam sebuah jurnal internasional milik Winter dalam Torelli University of Illinois di Urbana-Champaign dijelaskan bahwa, "people with a strong socialized power motive pursue prosocial goals for the benefit of some other person or cause and avoid negative effects on others." Dapat dikatakan bahwa seseorang dengan kekuatan yang disosialisasikan dengan motif kekuasaan yang kuat dapat mencapai tujuan prososial untuk kepentingan orang lain atau menghindari efek negatif pada orang lain. Yukl (2004:148) dalam bukunya Leadership in Organizations menjelaskan terkait kekuasaan, "power is useful for understanding how people are able to influence each other in organizations." Dapat dikatakan bahwa kekuasaan berguna untuk memahami bagaimana orang dapat saling mempengaruhi dalam organisasi. 
Berdasarkan konsep-konsep yang telah dikemukakan di atas, dapat disintesiskan bahwa kekuasaan adalah kekuatan seseorang dalam organisasi untuk mempengaruhi sikap, nilai, kepercayaan dan perilaku seseorang ke arah yang diinginkan dengan indikator: (1) memberikan bantuan, (2) merubah perilaku, (3) mengarahkan, (4) kepedulian reputasi, (5) mengendalikan.

\section{Kepercayaan}

Berbicara kepercayaan, Campbell dan Nelson (2009:416) mendefinisikan kepercayaan sebagai, "trust is the willingness to be vulnerable to the actions of another." Kepercayaan adalah kesediaan untuk peka terhadap tindakan orang lain. Selanjutnya Cook dan Philip (2001:319) memberikan definisi terkait kepercayaan yaitu, "trust is the degree to which you believe someone else is honest and supportive". Kepercayaan adalah sejauh mana Anda percaya orang lain itu bersikap jujur dan mendukung.

Adapun Robbins dan Coulter (2007:536-537) mengemukakan bahwa kepercayaan adalah, "trust is defined as the belief in the integrity, character, and ability of a leader". Dapat diartikan bahwa kepercayaan didefinisikan sebagai keyakinan pada integritas, karakter, dan kemampuan seorang pemimpin. Demikian pula yang dikemukakan oleh Kreitner dan Kinicki (2010:318) bahwa kepercayaan adalah, "trust is defined as reciprocal faith in other's intentions and behavior." Kepercayaan didefinisikan sebagai keyakinan yang berakibat timbal balik pada intensitas dan perilaku orang lain.

Seiring dengan Kreitner dan Kinicki, Colquitt dan Wesson (2009:452) mengemukakan, "trust is defined as the willingness to be vulnerable to an authority based on positive expectations about the authority's actions and intentions." Kepercayaan didefinisikan sebagai kesediaan untuk patuh terhadap sebuah otoritas yang berdasarkan pada harapan positif mengenai tindakan dan keinginan. Lussier (2010:296) mengatakan hal yang sama, bahwa kepercayaan adalah, "trust is the positive expectation that another will not take advantage of you." Kepercayaan adalah harapan positif yang mana orang lain tidak akan mengambil keuntungan dari Anda.

Jackson dan Mathis (2003:82) menjelaskan bahwa, "one key organizational value that effects employee retention is trust." Di mana dikatakan bahwa salah satu kunci dari nilai organisasi sebagai efek bertahannya karyawan adalah kepercayaan.

Berdasarkan konsep-konsep di atas dapat disintesiskan bahwa kepercayaan ialah kesediaan untuk patuh terhadap sebuah otoritas yang berdasarkan pada harapan positif mengenai tindakan dan keinginan orang lain dengan indikator: (1) mendukung, (2) kesediaan untuk peka, (3) keyakinan pada kemampuan, (4) integritas, dan (5) harapan positif.

\section{METODE}

Penelitian ini dilakukan di Sekolah Dasar Negeri (SDN) Rawalumbu, Bekasi. Waktu uji coba dilakukan dari Juni 2013 hingga Juli 2013 sedangkan waktu penelitian dilakukan bulan Juli 2013 sampai bulan Agustus 2013. Penelitian ini menggunakan metode penelitian survey dengan pendekatan kuantitatif-kausal, dengan menggunakan analisis jalur (path analysis) Pendekatan ini dipilih untuk menganalisis pola hubungan antar variabel. Alat pengumpulan data pokok dan dokumentasi yang digunakan dalam penelitian ini adalah kuesioner.

Populasi target dalam penelitian ini adalah seluruh guru Sekolah Dasar Negeri (SDN) yang berada di kecamatan Rawalumbu Bekasi. Populasi terjangkaunya adalah Sekolah Dasar Negeri (SDN) yang berada di kelurahan Pengasinan yang terdiri dari 10 
Sekolah Dasar Negeri (SDN) dengan jumlah guru sebanyak 161 guru yang berada di wilayah kelurahan Pengasinan, Rawalumbu Bekasi. Pengambilan sampel dilakukan dengan menggunakan teknik sampel acak sederhana (simple random sampling) dengan cara diundi. Sampel yang akan digunakan dalam penelitian ini berjumlah 115 guru.

Sebelum kuesioner digunakan dalam penelitian ini terlebih dahulu dilakukan uji coba untuk menentukan validitas dan reliabitas instrumen. Hasil tersebut digunakan sebagai instrumen untuk mengambil data dalam penelitian di lapangan. Analisis data meliputi: 1) deskripsi data; 2) uji prasyarat analisis normalitas; 3) analisis jalur yang meliputi: analisis model, pengujian hipotesis dan penentuan tingkat pengaruh.

\section{HASIL DAN PEMBAHASAN}

\section{Pengaruh langsung positif Kekuasaan terhadap Organizational Citizenship Behavior}

Berdasarkan hasil perhitungan koefisien korelasi $r_{13}=0,423$ dan koefisien jalur $\mathrm{p}_{31}=0,322$. Dengan demikian terdapat pengaruh langsung positif kekuasaan terhadap organizational citizenship behavior. Hasil penelitian tersebut sesuai dengan konsep Hughes et al yang memberikan penjelasan mengenai definisi kekuasaan sebagai, "power is the capacity to cause change, influence is the degree of actual change in a target person's attitudes, values, beliefs, or behaviors." Kekuasaan adalah kemampuan yang dapat menyebabkan perubahan, mempengaruhi tingkat perubahan yang sebenarnya terhadap sasaran sikap, nilai, kepercayaan, atau perilaku seseorang.

Untuk organizational citizenship behavior (OCB) Robbins dan Timothy menyatakan, "organizational citizenship behavior (OCB) is discretionary behavior that is not part of an employee's formal job requirements but nevertheless promotes the effective functioning of the organization". Organizational citizenship behavior (OCB) adalah perilaku sukarela yang bukan merupakan bagian dari persyaratan formal seorang karyawan pada pekerjaannya namun ia tetap meningkatkan fungsi efektif dari organisasi.

Adapun teori yang menunjukkan pengaruh kekuasaan dengan organizational citizenship behavior menurut Colquitt, Lepine, and Wesson dalam bukunya mengatakan bahwa, "power and influence have a moderate positive effect on performance. When used effectively, they can increase internalization and compliance, which facilitates task performance. The internalization and compliance facilitated by power and influence can also increase Citizenship Behavior and decrease Counterproductive Behavior." Di mana dijelaskan bahwa kekuasaan dan pengaruh memiliki efek moderat positif pada kinerja. Ketika digunakan secara efektif, mereka dapat meningkatkan internalisasi dan kepatuhan, yang memfasilitasi kinerja tugas. Internalisasi dan kepatuhan difasilitasi oleh kekuasaan dan pengaruh juga dapat meningkatkan perilaku kewarganegaraan (citizenship behavior) dan mengurangi perilaku kontraproduktif.

Hasil penelitian ini sesuai dengan penelitian yang dilakukan oleh Brian P. Niehoff yang berjudul "A Motive-Based View of Organizational Citizenship Behaviors: Applying an Old Lens to a New Class of Organizational Behaviors" pada State University di Kansas yang mengatakan, "the power-oriented citizen invests in such capital by exhibiting OCB, and builds their power base with such exhibitions."

Hasil ini menunjukkan bahwa kekuasaan yang berorientasi pada citizenship dapat menjadi investasi sebagai modal untuk menunjukkan OCB tersebut, dan membangun dasar kekuasaan yang mereka tunjukkan. Hal ini mencerminkan bahwa semakin tinggi kekuasaan kepala sekolah maka semakin tinggi organizational citizenship behavior guru. 


\section{Pengaruh langsung positif Kepercayaan terhadap Organizational Citizenship Behavior}

Berdasarkan hasil perhitungan koefisien korelasi $\mathrm{r}_{23}=0,386$ dan koefisien jalur $\mathrm{p}_{32}=0,261$. Dengan demikian terdapat pengaruh langsung positif kepercayaan terhadap organizational citizenship behavior. Tentang kepercayaan Campbell dan Nelson menjelaskan bahwa, "trust is the willingness to be vulnerable to the actions of another." Kepercayaan adalah kesediaan untuk peka terhadap tindakan orang lain. Sementara organizational citizenship behavior sesuai dengan pendapat Greenberg yang mengatakan bahwa, "OCB is generally no included as part of any standard performance measures that a company gathers about its employees." OCB umumnya adalah tidak termasuk sebagai bagian dari ukuran standar kinerja bahwa sebuah perusahaan dapat memberikan fungsi karyawannya.

Hasil penelitian ini mendukung teori Miner yang mengungkapkan bahwa, "the question of the role of followers trust in transformational leadership has been a concern for some time, but it now is apparent that trust plays a positive mediating role between transformational leadership and organizational citizenship behaviors, which involve performances that go beyond expectantions and role requirements".

Pertanyaan mengenai peran pengikut kepercayaan dalam kepemimpinan transformasional telah menjadi perhatian beberapa waktu, namun sekarang jelas bahwa kepercayaan memainkan peran secara langsung positif antara kepemimpinan transformasional dan organizational citizenship behaviors, yang melibatkan kinerja untuk mencapai harapan dan peran yang dibutuhkan.

Mendukung teori tersebut Ivancevich menjelaskan dalam pernyataannya bahwa, " $a$ major influence on OCBs is the leadership that imployees received from their manager. Specifically, trust between an employee and a manager and a management style that encourages the development of leadership skills among employees have been found to encourage the expression of OCBs." Dikatakan bahwa sebuah pengaruh besar terhadap OCBs adalah kepemimpinan yang diperoleh para karyawan dari manajer mereka.

Secara khusus, kepercayaan antara karyawan dan seorang manajer dan gaya manajemennya dapat meningkatkan/mendorong perkembangan keterampilan di kalangan karyawan telah ditemukan dapat meningkatkan ekspresi OCBs. Hal ini mencerminkan semakin baik kepercayaan yang dimiliki guru terhadap kepala sekolah maka semakin tinggi tingkat organizational citizenship behavior guru.

\section{Pengaruh langsung positif Kekuasaan terhadap Kepercayaan}

Berdasarkan hasil perhitungan koefisien korelasi $\mathrm{r}_{12}=0,387$ dan koefisien jalur $\mathrm{p}_{21}=0,387$. Dengan demikian terdapat pengaruh langsung positif kekuasaan terhadap kepercayaan. Mengenai kekuasaan, McShane mengemukakan bahwa, "power is the capacity of a person, team, or organization to influence others."

Dapat diartikan bahwa kekuasaan adalah kemampuan seseorang, tim, atau organisasi untuk mempengaruhi orang lain. Sementara tentang kepercayaan Robbins dan Coulter mengemukakan bahwa kepercayaan adalah, "trust is defined as the belief in the integrity, character, and ability of a leader". Dapat diartikan bahwa kepercayaan didefinisikan sebagai keyakinan pada integritas, karakter, dan kemampuan seorang pemimpin.

Adapun teori yang menunjukkan pengaruh kekuasaan terhadap kepercayaan Yukl memberikan penjelasan, "referent power is increased by showing concern for the needs and feelings of others, demonstrating trust and respect, and treating people fairly." Di mana 
ditunjukkan bahwa kekuasaan yang berlandaskan pada acuan maka dapat terjadi peningkatan dengan memperlihatkan kepedulian terhadap kebutuhan dan perasaan orang lain, menunjukkan kepercayaan dan rasa hormat, dan menangani orang yang gagal.

Mendukung teori tersebut Johnson memberikan penjelasan bahwa "unequal power interferes with the trust and communication necessary for managing group conflicts constructively." Kekuasaan yang tidak seimbang dapat mengganggu kepercayaan dan komunikasi yang diperlukan untuk mengelola konflik kelompok secara konstruktif. Dari penjelasan tersebut maka dapat dipahami bahwa jika kekuasaan tersebut seimbang maka dapat meningkatkan kepercayaan. Hal ini mencerminkan bahwa semakin tinggi kekuasaan maka semakin tinggi pula kepercayaan yang dimiliki guru.

\section{PENUTUP}

Kesimpulan. Berdasarkan hasil penelitian ini dapat disimpulkan bahwa :

1. Terdapat pengaruh positif kekuasaan terhadap organizational citizenship behavior yang ditentukan oleh derajat besarnya pengaruh dalam bentuk koefisien korelasi dan koefisien jalur. Selanjutnya dapat diketahui signifikansi pengaruh antara kekuasaan terhadap organizational citizenship behavior secara parsial. Hal ini memiliki makna dan penegasan bahwa kekuasaan secara empiris bukan satu-satunya variabel prediktor bagi varians skor organizational citizenship behavior.

2. Terdapat pengaruh positif kepercayaan terhadap organizational citizenship behavior yang ditentukan oleh derajat besarnya pengaruh dalam bentuk koefisien korelasi dan koefisien jalur. Selanjutnya dapat diketahui signifikansi pengaruh antara kepercayaan terhadap organizational citizenship behavior secara parsial. Hal ini memiliki makna dan penegasan bahwa kepercayaan secara empiris bukan satusatunya variabel prediktor bagi varians skor organizational citizenship behavior.

3. Terdapat pengaruh positif kekuasaan terhadap kepercayaan yang ditentukan oleh derajat besarnya pengaruh dalam bentuk koefisien korelasi dan koefisien jalur. Selanjutnya dapat diketahui signifikansi pengaruh antara kekuasaan terhadap kepercayaan secara parsial. Hal ini memiliki makna dan penegasan bahwa kekuasaan secara empiris bukan satu-satunya variabel prediktor bagi varians skor kepercayaan. 
Saran. Beberapa hal yang disarankan dalam penelitian ini adalah sebagai berikut:

1. Untuk meningkatkan organizational citizenship behavior guru, maka para kepala sekolah selaku pimpinan dan manajer dalam satuan pendidikan hendaknya dapat menjadikan dirinya sebagai panutan (role model) bagi anggotanya untuk dicontoh dan dapat mengerahkan anggota dalam menjalani tugas organisasi, serta dapat mengembangkan sumber daya yang ada dalam lingkup lembaga yang dipimpinnya.

2. Untuk meningkatkan kepercayaan guru, maka hendaknya kepala sekolah mampu membina komunitas sekolah untuk selalu tertantang dalam mencapai standar yang tinggi dalam mencapai mutu pendidikan, dan mampu memahami yang terbaik untuk anggota organisasi, serta memiliki integritas yang ditunjukkan melalui perilaku profesional.

3. Bagi para peneliti lain, dapat memperluas penelitian dengan melibatkan lebih banyak variabel lain yang diduga berkorelasi positif dengan organizational citizenship behavior guru. 


\section{DAFTAR RUJUKAN}

Colquitt, Lepine, and Wesson. Organizational Behaviour: Improving Performance in the Workplace. New York: McGraw-Hill, 2009.

Cook, Curties W., Philip L. Hunsaker. Management and Organizational Behavior. Third Edition, New York: McGraw-Hill, 2001.

Gibson, Ivancevich, Denelly, Konopaske. Organizations Behaviors, structure, process. International edition. Singapore: McGraw-Hill, 2006.

Greenberg, Jerald, Robert A. Baron. Behavior in Organizations. Ninth Edition. New Jersey: Pearson Prentice Hall, 2008.

Hall, Richard H. Organizations, structure, processes, and outcomes. New Jersey: Prentice Hall, 2002.

Hughes, Richard L., Robert C. Ginnet, Gordon J. Curphy. Leadership Enhancing the Lessons of Experience. Sixth Edition. New York: McGraw-Hill, 2009.

Karfestani, Zahra Jafari, Mostafa Azizi Shomami, Moslem Maleki Hasanvand. Organizational Citizenship Behavior as an Unavoidable Necessity for increasing the Effectiveness of Organizations. ijcrb.webs.com INTERDISCIPLINARY JOURNAL OF CONTEMPORARY RESEARCH IN BUSINESS COPY RIGHT @ 2013 Institute of Interdisciplinary Business Research 827 JANUARY 2013 VOL 4, NO 9 h. 827 (diakses pada 20 April 2013)

Kreitner, Robert, Angelo Kinicki. Organizational Behavior. Ninth Edition, New York: McGraw-Hill, 2010.

Lussier, Robert N., Ph.D. Human relations in Organizations Applications and Skill Building. Eighth Edition. New York: McGraw-Hill, 2010.

Mathis, Robert L., John H. Jackson. Human Resource Management. Tenth Edition. United States of America: Thomson, 2003.

McShane, Von Glinow. Organizational Behavior. Fifth Edition. United States: McGrawHill, 2010.

Newstroom, John W.,Keith Davis. Organizational Behavior human behavior at work. International Edition. New York: McGraw-Hill, 2002.

Robbins, Stephen P., Timothy A. Judge. Organizational Behavior. Fourteenth Edition. New Jersey: Pearson, 2011.

Schermerhorn, Hunt, Osborn, Uhl-Bein. Organizational Behavior. Eleventh Edition. USA: John Wiley \& Sons (Asia), 2011. 
Quick, James Campbell, Debra L. Nelson. Principles of Organizational Behavior Realities and Challenge. China: South-Western Cengange Learning, 2009.

Yukl, Gary. Leadership in Organizations. Sixth Edition. New York: Albany, 2004. 